\title{
媨と意識に関するTokyo'99 国際会議
}

\section{久保田 直行*}

本国際会議は, 1999 年 5 月 25 日から 28 日にか けて, 東京の国際連合大学本部の国際会議場にて 行われた（図1). 国内の案内では，日本語で“脳と 意識に関するTokyo'99 国際会議”と書かれてい たが，実際は，“Toward a Science of Consciousness - Fundamental Approaches - Tokyo '99" で ある. 本国際会議では, 脳組織の如何なる機能並び に素過程から意識が生じるか, 認知科学, 哲学, 情 報科学, 数学, 物理学, 生命科学などの観点による 数多くの最新の研究結果の発表が行われた。保江 邦夫委員長を中心に組織され, 北アメリカ, ヨーロ ッパ，国際連合から 20 名，国内から 9 名を迎えた 世界的に著名な科学者と哲学者による特別講演の 他, 一般講演, ポスター発表が行われた. 参加者数 は, 定員 300 名の予定であったが, 参加希望者多数 のため, 結局, 国内外あわせて 388 名となった。

Proceedingsは, 出版社より単行本として, 後日, 発行される予定であり, Abstractのみ, Souvenir Programmeの中に収録されていた。

会議は, シングルセッションで行われ, 大きく分 けて, 以下の 4 テーマから構成され, 各日に割り当 てられている。

- What are we?

-What is mind?

- What is reality?

- What is life?

初日は,まず, T.D.Senta 先生と保江委員長の開 会の挨拶からはじまった. 次に, 哲学・倫理学から のアプローチとして, “What are we ?”をテーマ に, 以下のような特別講演が行われた. Fundamental Theories of Consciousness (D.Chalmers), The Philosophies of Mind and Science (W. Seager), On the Role of the Subject in Science (P.Hut), Consciousness in Action (S.Tutiya),
Consciousness as a Quantum Mechanical Observable (M.Lockwood), A Human Being as an Experiencing Physical System ( $P$. Pylkkanen)。その後, 会議場全体のグループ撮影 が行われ,一般講演とポスター発表は, 夕方に行わ れた. ポスター発表は, 少し, 狭い場所で行われた ため,ひしめき合いながらも活発な討論が行われ ていた.

二日目は, 心理学・認知科学からのアプローチと して, “What is mind ?”をテマに, The Dreaming Brain and the Conscious States Paradigm (A.Hobson), Brain and the Composition of Conscious Experience (K.Pribram), Are There Neural Correlates of Becoming Aware? A Study Case (F.Varela), Reality and Actuality: The Interaction between the Environment and the Mind (H.Nakashima), The Bodhisattva Hypothesis: Scientific Studies of Consciousness Have Implications for the Values We Bring to Them (B.Baars), A Cascade Hypothesis of Brain Functions and Consciousness (G. Takeda), Neural Correlates of Consciousness (N.Osaka)の特別講演が行われた. 特別講演後, 今

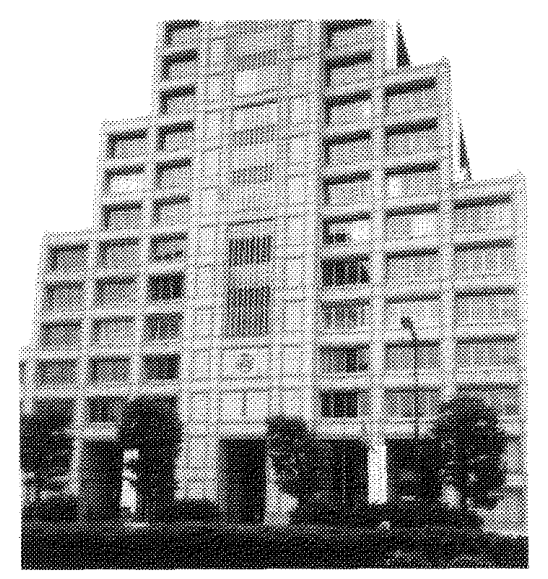

図1 国際連合大学の風景 
回の目的の一つである京都大学の苧阪直行先生と 写真を撮ることができ，筆者は非常に満足してい る(困 2). 特別講演の後, 初日同様, 一般講演とポ スター発表が行われた。

三日目は, 物理学・数学・情報科学からのアプロ ーチとして, “What is reality?”をテーマに, The Mind of Brain (G.Matsumoto), The MindBody and Light-Matter (M.Jibu), Dissipative Quantum Brain Dynamics (G.Vitiello), Consciousness and Quantum Foundation: Where are We Now? (P.Werbos), Mathematics and the Mind (E.Nelson), Physical Limitations on the Formulation of Mental States as Emergent Phenomena (S.Hagan), The Mind of Quantum-Mind (G.Globus), The Open Mind (S.J.Nelson), Quantum Monadology: A Consistent World Model for Physics and a Descriptive Method for Game-Theoretical Situations (T. Nakagomi)の特別講演が行われ, 次に一般講演が 行われた。

最終日は, 生物学・生命科学からのアプローチと して, “What is life?”をテーマに, Study of Life Science by Information Dynamics (M.Ohya), From Chemicals to Consciousness (S.Greenfield), The Importance of Experience: Where for the Future? (B.Josephson), Microtubes as Smart Bioelectronic Devices (J.Tuszynski), Quantum Vitalism' - Are Consciousness and the 'Living State' Fundamental Quantum Processes ? (S.Hameroff)の特別講演が行われた. 一般講演 の後, 治部先生と T.D.Senta 先生により,「人間の 脳と意識に関する科学的研究の成果が人類の平和

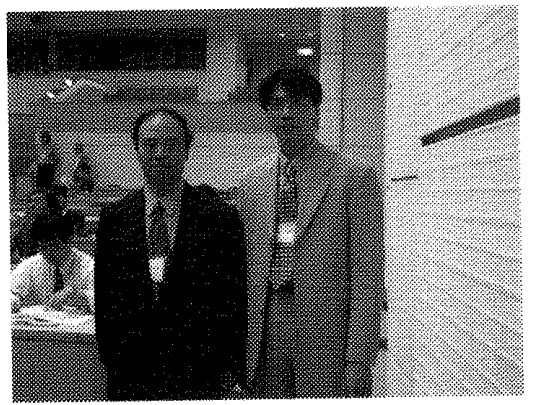

図 2 特別講演後、苧阪值行先生(左) と筆者

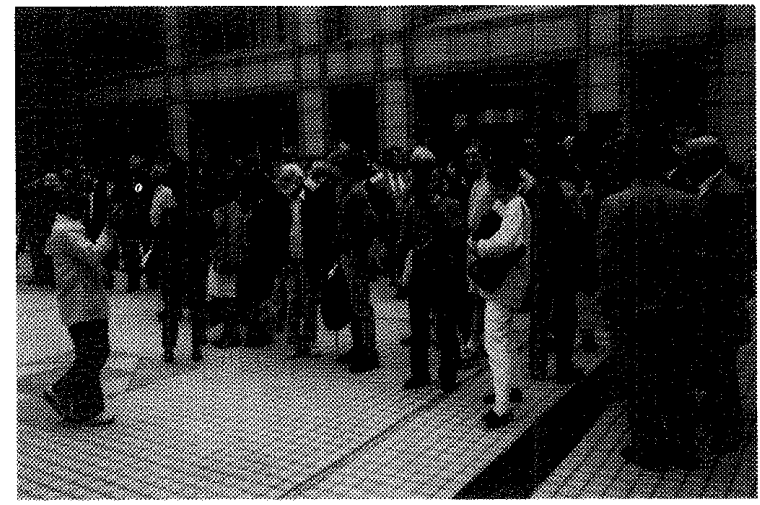

図 3 中庭でのグループ撮影の風景

と福祉のみのために用いられ，決して謝った方向 に利用されることがないように」と” Tokyo'99 宣 言”が行われ, 最後に, H.V.Ginkel 先生と保江委 員長による閉会挨拶により，無事，会議が終了し た. 会議終了後, 参加者全員が中庭に集合し, 会議 場の屋上から見おろす形でグループ撮影が行われ た(図 3)。また，質疑応答パーティがコープイン渋 谷で行われたが, 残念ながら, 時間の関係上, 筆者 は参加できなかった。

筆者は, このような内容の国際会議への参加は 初めてであり，非常に興味深く，楽しみにしてい た. 当日, 参加してみると, 講演では, 基本的に数 式の使用が一切, 禁止されており, 直感的な理解が 少し, 困難に思えたのが正直な感想であるが, 素人 である筆者でさえ，概念的な部分の奥深さが味わ えたような気がする.実際, 知的エージェントの知 賞機構に関する研究の新しい方向性を見いだせた 気がする.紙面の制限の関係上, 各講演内容の記述 を割愛させていただくことにする.

次回は，米国アリゾナ州の Tucsonにて，2000 年 4 月 10 日から 15 日にわたり, 開催される予定 である. 本国際会議の情報とともに, 以下のホーム ページに詳細情報が述べられている。

http://www.ndsu.ac.jp/ tokyo 99/ http://www.consciousness.arizona.edu/

[問い合わせ先]

干 535-8585 大阪市旭区大宮 5-16-1 大阪工業大学工学部機械工学科

久保田 直行

TEL：06-6954-4254

FAX : 06-6957-2134

E-mail : kubota@med.oit.ac.jp 